\title{
Call for Contributions:
}

ICOPA XIII - Thirteenth International

Conference on Penal Abolition

Belfast, Northern Ireland

ICOPA International Organizing Committee

$\mathrm{T}$

The expansion and normalization of imprisonment as a tool for dealing with a wide range of social problems has led to the entrenched perception of prisons as seemingly permanent fixtures of the modern landscape. In most academic and political circles, debates about prisons and penal policy are limited to discussions of 'reform', with little serious problematization of the underlying structure. Penal abolitionism - as a perspective, theory and international movement - presents a vital alternative to this penal inertia. Abolitionists reject the presumed inevitability of the prison and actively seek to oppose and dismantle the prison-industrial complex, while advancing community-based and non-punitive alternatives to imprisonment as part of a broader strategy of social transformation.

The voices of prisoners have been central to past abolitionist debates, and have helped to shape the theoretical and political terrain of the international abolitionist movement. The Journal of Prisons on Prisons (JPP) itself emerged out of the proceedings of the Third International Conference on Penal Abolition (ICOPA III), held in Montreal in 1987. Since that time, the $J P P$ has dedicated two thematic issues - Volumes 1(1) and 17(2) - to the topic of abolition. Moving forward, we hope to reinvigorate abolitionist thought and action by once again placing the voices of those most affected by the system at the centre of the debate.

The JPP is seeking original submissions on the theme of penal abolitionism, for the purpose of preparing a special issue or Dialogues section. Papers on a wide range of topics related to abolitionism are welcome. In particular, we invite contributions that deal with:

1. Theoretical engagements with penal abolitionism - engagements with classical abolitionist texts and discussions of new directions for abolitionist theory.

2. Abolitionist practices and the penal abolitionist movement discussions of the "how" of penal abolitionism, the scope and nature of the movement, and especially on the roles played by prisoners. Papers might engage with art, writing and expression as resistance in 
an abolitionist context.

3. Reflections on the goals of contemporary penal abolitionism reconciling abolitionist goals (both short- and long-term) with the current state of the carceral, and engagements with the question "what is to be abolished?". For example, contributions could touch upon issues such as access to health care, mental health care and harmreduction in prisons, political imprisonment, immigration detention and torture, gender and sexuality, youth incarceration and mandatory minimum sentencing, and the role of private enterprise.

4. Why abolition, why now? - works that ground discussions of abolitionism in the experiences and accounts of prisoners.

Please provide us with a draft article by no later than March 1, 2010. Selected papers submitted by that time may be considered for presentation, read by the author or a delegate, at the Thirteenth International Conference on Penal Abolition (ICOPA XIII) to take place in summer 2010 at Queen's University - Belfast, Northern Ireland.

Submissions can be sent by e-mail to jpp@uottawa.ca or by post to:

Journal of Prisoners on Prisons

c / o University of Ottawa Press

542 King Edward Avenue

Ottawa, Ontario, Canada

K1N 6N5 